\title{
EFFECTS OF TEMPERATURE ON THE SURVIVAL AND GROWTH OF AGE-0 LEAST CHUB (IOTICHTHYS PHLEGETHONTIS)
}

\author{
Eric J. Billman ${ }^{1}$, Eric J. Wagner ${ }^{1,2}$, and Ronney E. Arndt ${ }^{1}$
}

\begin{abstract}
Larval and juvenile stages of many fishes require nursery habitats that provide optimal conditions for growth. Loss or degradation of these habitats limits recruitment, causing population and species declines. Least chub (Iotichthys phlegethontis), an endemic cyprinid in the Bonneville Basin, is currently restricted to a few spring complexes in Utah. This species utilizes the warm shallow spring margins as spawning and rearing habitat throughout the summer. This study was conducted to determine effects of temperature on survival and growth of age-0 least chub to understand the importance of temperature in selection of spring margins as rearing habitat. Age-0 least chub were exposed to 5 temperatures $\left(14^{\circ} \mathrm{C}, 17^{\circ} \mathrm{C}, 21^{\circ} \mathrm{C}, 24^{\circ} \mathrm{C}\right.$, and $\left.27^{\circ} \mathrm{C}\right)$ for 112 days. Growth rates varied significantly with temperature except at $17^{\circ} \mathrm{C}$ and $27^{\circ} \mathrm{C}$, and growth rates were highest at $21^{\circ} \mathrm{C}(P<0.001)$. Maximum growth rate for age-0 least chub, estimated from a 2 nd-order polynomial regression, would occur at $22.3^{\circ} \mathrm{C}$. These thermal requirements indicate the importance of warm rearing habitats in producing strong year classes and viable populations. However, warm spring margins also enable western mosquitofish, a nonnative competitor and predator of least chub, to thrive in these spring habitats. Broad thermal limits of the least chub suggest that it could persist at cooler temperatures, which would reduce the viability of western mosquitofish populations.
\end{abstract}

Key words: temperature, growth efficiency, least chub, Iotichthys phlegethontis, Great Basin, cyprinid.

Fish species often require a variety of habitats throughout their life history (Werner and Hall 1988, Rosenberger and Angermeier 2003). Changes in habitat preferences result from differences among each life history stage in resource utilization (Rosenberger and Angermeier 2003), predator avoidance (Power 1984, Werner and Hall 1988, Angermeier 1992), or physiological tolerance (Mann and Bass 1997, Robinson and Childs 2001). To be effective in conserving or restoring fish populations, managers must understand the ontogeny of habitat requirements many fish exhibit across their development.

Larval and juvenile stages of many fish require nursery habitat that offers suitable environmental conditions for growth including abundant prey, optimal physical parameters (i.e., temperature, dissolved oxygen, and flow), and protection from predators (Scheidegger and Bain 1995, Sandström and Karås 2002). The importance of seasonally inundated floodplains as spawning and nursery habitats has been documented for many fish taxa (Neill and Turner 1987, Kwak 1988, Snedden et al. 1999). Recruitment for these species is directly associated with connectivity to and quality of these habitats, making early life stages particularly vulnerable to anthropogenic disturbances (Bulak et al. 1997, Modde et al. 2001). Human alterations to nursery habitats, such as channel straightening, flow regulation, siltation, and introduction of nonnative competitors or predators, reduce recruitment and cause population and species declines (Berkman and Rabeni 1987, Robinson and Childs 2001, Olsen and Belk 2005).

The least chub (Iotichthys phlegethontis) is native to the Bonneville Basin, Utah, where it was once widespread in rivers, streams, creeks, springs, ponds, marshes, and swamps (Sigler and Sigler 1996). Anthropogenic disturbances, including habitat loss and introduction of nonnative species, have extirpated least chub from much of their historical range (Perkins et al. 1998). Current populations of least chub are limited to a few isolated spring complexes in the Snake Valley of western Utah and in Mona Springs and Mills Valley in central Utah.

Least chub exhibit a seasonal shift in habitat for spawning and rearing associated with temperature changes within spring complexes. In April and May, adult least chub move out of pool areas created by the spring and into shallow

${ }^{1}$ Utah Division of Wildlife Resources, Fisheries Experiment Station, 1465 West 200 North, Logan, UT 84321.

${ }^{2}$ Corresponding author. E-mail: ericwagner@utah.gov 
water on the spring margins to reproduce. This movement begins when water temperatures reach approximately $16^{\circ} \mathrm{C}$ (Sigler and Sigler 1996, Perkins et al. 1998). Least chub are partial and intermittent spawners, depositing adhesive and demersal eggs on vegetation and other suspended substrates (Crawford 1979). Spawning lasts throughout the summer months. Adult and age- 0 least chub return to pool habitats as temperatures decrease during late summer and early fall. Water temperatures in the spring margins can fluctuate between $15^{\circ} \mathrm{C}$ and $32^{\circ} \mathrm{C}$ during the summer (Perkins et al. 1998). Abundant prey (algae and macroinvertebrates) and warmer water in spring margins are presumed benefits for age- 0 least chub that allow them to grow sufficiently to avoid overwinter mortality (Sigler and Sigler 1987, Shuter and Post 1990). The shallow water habitat, however, could be as or more important in providing protection from aquatic predators (Power 1984, Werner and Hall 1988, Angermeier 1992).

Least chub has been designated a sensitive species by the state of Utah because the species is at risk of becoming threatened or endangered. A multiagency conservation agreement has been established by the state of Utah that outlines management priorities that will attempt to stop further declines and begin recovery of the species (Perkins et al. 1998). Current conservation efforts include development of hatchery facilities, establishment of refuge habitat, and expansion of populations within the historical range. Understanding thermal requirements of this species, particularly for juveniles, will not only help to establish protocols for rearing facilities, but will also elucidate the importance of warm, shallow spring margins for growth of age-0 least chub and subsequent recruitment. Juvenile fish have higher optimal growth temperatures than adult fish; if least chub demonstrate this ontogeny, management of the species should include protection of shallow spring margin habitat (Gerking and Lee 1983). Herein we present the effects of temperature on survival and growth of age-0 least chub and discuss management implications of our results.

\section{Methods}

We conducted this study at the Utah Division of Wildlife Resources Fisheries Experi-
TABLE 1. Mean temperatures and least chub survival for each treatment over the duration of the study. One standard deviation $(s)$ is shown in parentheses.

\begin{tabular}{ccc}
\hline $\begin{array}{c}\text { Target temperature } \\
\left({ }^{\circ} \mathrm{C}\right)\end{array}$ & $\begin{array}{c}\text { Measured } \\
\text { temperature }\left({ }^{\circ} \mathrm{C}\right)\end{array}$ & $\begin{array}{c}\text { Survival } \\
(\%)\end{array}$ \\
\hline 14 & $14.15(0.100)$ & $99(0.025)$ \\
17 & $17.27(0.340)$ & $83(0.115)$ \\
21 & $21.11(0.499)$ & $91(0.087)$ \\
24 & $24.28(0.525)$ & $96(0.043)$ \\
27 & $27.33(0.695)$ & $86(0.100)$ \\
\hline
\end{tabular}

ment Station (FES) in Logan, Utah. Age-0 least chub were produced in fall 2004 using wild broodstock from Mona Springs, Utah, maintained at the FES. After hatching, age-0 least chub were held in $16^{\circ} \mathrm{C}$ well water until testing. Least chub ranged from 64 days to 106 days old at the beginning of the study.

Aquaria were set up in a flow-through system. Cold well water $\left(14^{\circ} \mathrm{C}\right)$ was mixed with warm well water (heated to $18^{\circ} \mathrm{C}$ with one 1 $\mathrm{kW}, 240-\mathrm{V}$ and two $6-\mathrm{kW}, 240-\mathrm{V}$ water heaters) in separate head boxes to achieve test temperatures of $14^{\circ} \mathrm{C}, 17^{\circ} \mathrm{C}, 21^{\circ} \mathrm{C}, 24^{\circ} \mathrm{C}$, and $27^{\circ} \mathrm{C}$. Temperatures in the test tanks were maintained throughout the study with minimal fluctuations (Table 1). Prior to mixing in the head boxes, water from each source was passed through degassing columns. Each head box supplied water to three $38-\mathrm{L}$ aquaria at a rate of $0.61 \mathrm{~L} \cdot \mathrm{min}^{-1}$. All aquaria and connecting pipes were covered with insulation to minimize temperature fluctuations. A full spectrum fluorescent light (two 4-ft bulbs) provided a $14 \mathrm{~h}: 10 \mathrm{~h}$ (light:dark) photoperiod.

On 2 December 2004, 23 age-0 least chub were randomly assigned to each aquarium. Mean initial total lengths of the 345 test fish were estimated from a subsample of 115 fish. A digital image was taken from above and total lengths determined using imaging software (Adobe Photoshop 5.5). Mean starting weights were estimated from a length-weight regression determined from 11 mortalities $\left(r^{2}=\right.$ $0.9763, P<0.0001)$. The 345 test fish averaged $15.5 \mathrm{~mm}$ total length and $32 \mathrm{mg}$ at the beginning of the study. Least chub were placed into aquaria, which were already at treatment temperatures, with no time for acclimation. Fish were held at test temperatures for 112 days to simulate the duration of exposure to seasonal high or low temperatures (Selong et al. 2001). 
Least chub were fed a mixed diet of a ground commercial flake feed (TetraMin ${ }^{\circledR}$ ) and frozen brine shrimp (Artemia franciscana) nauplii. The initial diet (Days 1-84) consisted of $84 \mathrm{mg}$ flake feed and $88 \mathrm{mg}$ brine shrimp per day per tank. After Day 84, the amount of brine shrimp was increased to $132 \mathrm{mg}$ per day. All tanks received the same amount of feed and each tank received at least $3.6 \%$ of the total fish biomass per day. Because waste feed had to be cleaned out of each tank on a regular basis, we assumed all fish were fed to excess.

Mortalities were removed daily, and total length and weight of these individuals were measured. Differences in percent survival among temperatures were analyzed using the Kruskal-Wallis test, because the arcsin-transformed data did not meet assumptions of normality and homogeneity of variances. Water temperature from a single tank within each treatment was monitored with a Hobo ${ }^{\circledR}$ Water Temp Pro logger, which recorded temperature every 3 hours. Each week we downloaded temperatures and rotated the dataloggers among treatment replicates.

Lengths and weights of least chub in each tank were measured at the end of the experiment (112 days). Lengths were measured using digital images as previously described. Final weights for fish within each tank were obtained by placing all remaining fish into a pre-weighed beaker of water, measuring the increase in total weight, and dividing by the number of fish. Care was taken to avoid introducing water with the fish. Absolute growth rate was calculated according to the formula $G=\left(Y_{t}-Y_{i}\right)$. $t^{-1}$, where $Y_{t}$ is the mean weight at time $t, Y_{i}$ is the initial mean weight, and $t$ is the number of days (Ricker 1979). Because the data were parametric, differences in growth rates among temperatures were compared via a 1-way analysis of variance (ANOVA). Post hoc comparisons were conducted with the Tukey test. Optimal temperature range for growth was determined by fitting the data (mean growth rate per tank and actual temperature) to a 2 ndorder polynomial regression. All analyses were performed using SPSS, version 7 (SPSS, Inc. 1996), and plotted using SigmaPlot, version 7 (SPSS, Inc. 2001).

\section{RESUlTS}

Survival of least chub ranged between $83 \%$ at $17^{\circ} \mathrm{C}$ and $99 \%$ at $14^{\circ} \mathrm{C}$ (Table 1 ) and was not significantly different between treatments $\left(\chi^{2}{ }_{4}\right.$ $=6.73, P=0.15)$. The growth of least chub varied significantly between temperature treatments except at $17^{\circ} \mathrm{C}$ and $27^{\circ} \mathrm{C}\left(F_{4,14}=\right.$ $285.22, P<0.001)$. The fastest growth rate (2.46 $\mathrm{mg} \cdot \mathrm{d}^{-1}$ or $7.7 \%$ of body mass per day) was achieved in the $21^{\circ} \mathrm{C}$ treatment tanks and the lowest growth $\left(0.61 \mathrm{mg} \cdot \mathrm{d}^{-1}\right.$ or $1.9 \%$ of body mass per day) in the $14^{\circ} \mathrm{C}$ tanks. The peak growth rate estimated by the 2 nd-order polynomial regression occurred at $22.3^{\circ} \mathrm{C}$ (Fig. 1). Least chub reared at $21^{\circ} \mathrm{C}$ and $24^{\circ} \mathrm{C}$ were the most active, swimming freely throughout the tanks. At higher or lower temperatures, least chub remained predominantly near or in contact with the bottom of the tanks. The upper and lower thermal limits to growth as predicted from the regression line (intersection of regression line with the $\mathrm{x}$-axis) were $32.2^{\circ} \mathrm{C}$ and $12.5^{\circ} \mathrm{C}$, respectively.

\section{Discussion}

High water temperatures are important for growth and survival of many cyprinid fishes (Mills 1991). Mills and Mann (1985) supplied evidence that year-class strength of some cyprinids was significantly correlated with temperature; years with high temperatures closer to the species' optimal growth temperatures gave rise to exceptional year-classes, presumably resulting from good growth and survival. Juveniles of riverine fishes utilize floodplain habitats that offer a more favorable environment than the main channel because temperatures are increased towards optimal growth temperatures; growth in these wetlands is much greater than in the cooler main channel (Junk et al. 1989, Sabo and Kelso 1991, Modde et al. 2001). Habitats offering optimal growth temperatures enable juvenile fish to grow large enough to escape predation and to avoid overwinter mortality (Shuter and Post 1990, Mills 1991, Durham and Wilde 2005).

Maximum growth of age-0 least chub in this study occurred at temperatures above the annual temperature range of the spring head at Mona Springs $\left(12^{\circ}-16^{\circ} \mathrm{C}\right)$. These data indicate the importance of the warm, shallow water habitat associated with springs for development and growth of age-0 least chub. Temperature at which maximum growth was achieved $\left(22.3^{\circ} \mathrm{C}\right)$ was similar to temperatures at which other early life history development rates (e.g., 


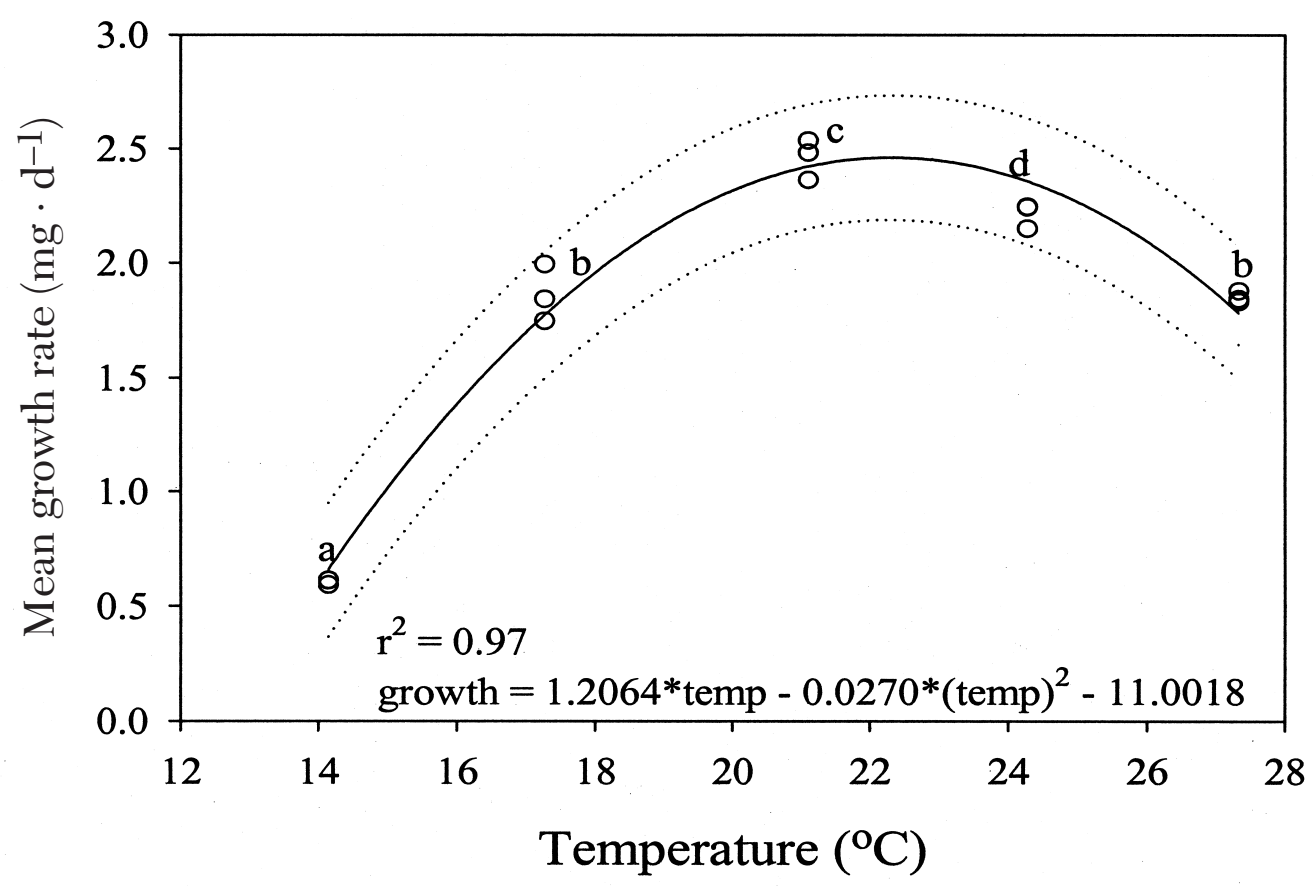

Fig. 1. Growth of age-0 least chub in relation to temperature. Each circle represents the mean individual weight gain of fish $(n=23)$ for each tank at each treatment temperature. Dotted lines indicate the $95 \%$ prediction interval of the regression line. The coefficient of determination is also presented. Letters indicate significant differences in growth among temperatures.

time-to-hatch and time of first feeding) are maximized. Crawford (1979) reported that least chub eggs hatched in 2.1 days at $22.2^{\circ} \mathrm{C}$. Least chub hatch at an early stage of development, lacking fins and mouthparts at time of hatch. Full development and onset of external feeding occurs in approximately 3 days posthatch at $22^{\circ} \mathrm{C}$ (Crawford 1979). A decrease of $4^{\circ} \mathrm{C}$ would double the time for eggs to hatch and least chub to begin feeding (Crawford 1979; R. Arndt, Utah Division of Wildlife Resources, unpublished data). According to our study, a drop in temperature from $22^{\circ} \mathrm{C}$ to $18^{\circ} \mathrm{C}$ would result in a $20 \%$ decrease in growth rate of age- 0 least chub. Thus, increased growth rates achieved in these warmer habitats likely increases the fitness of age-0 least chub by allowing them to grow large enough to avoid predation and overwinter mortality and to reach reproductive maturity by age 1 (Crawford 1979, Shuter and Post 1990).

Broad thermal limits, as predicted for age- 0 least chub, are not uncommon for minnows in western North America. These cyprinids often live in habitats that subject them to a wide range of temperatures because of the arid climate and harsh winters. Examples of other temperature tolerant cyprinids include the Utah chub (Gila atraria; $15^{\circ}-31^{\circ} \mathrm{C}$; Sigler and Sigler 1987), the desert dace (Eremichthys acros; $18.0^{\circ}-40.5^{\circ} \mathrm{C}$; U.S. Fish and Wildlife 1997), and the Borax Lake chub (Gila boraxobius; $17^{\circ}-35^{\circ} \mathrm{C}$; Williams and Bond 1983). While these fishes are tolerant to a wide range of temperatures, specific temperatures are necessary for spawning, egg development, and growth of juveniles (Williams and Bond 1983, U.S. Fish and Wildlife 1997). Changing weather patterns from year to year and anthropogenic disturbances to watersheds (i.e., dewatering, channel straightening, and siltation) can contribute to variable year-to-year recruitment and abundance; the additive effects of these factors has caused the decline of many cyprinid species (Cross 1978, Black and Bulkley 1985, Castleberry and Cech 1986, Blinn et al. 1998).

This study has implications for species management, habitat management, and site selection for recovery efforts. Within habitats currently occupied by least chub, managers should 
make efforts to maintain the shallow water habitats associated with spring complexes. Cattle grazing and seasonal dewatering for irrigation purposes likely minimize the availability of shallow habitats and the duration that these habitats can be utilized by age-0 least chub (Perkins et al. 1998). By maintaining connections to shallow habitats, managers afford least chub the opportunity to produce strong-year classes and stable, viable populations (Mills and Mann 1985, Modde et al. 2001). Sites that managers select for reintroductions should have access to warm, productive habitats to maximize growth and survival. Without access to these habitats, least chub will likely not produce strong populations at the new sites, and the populations will be susceptible to extirpation from predation, competition, or anthropogenic disturbances.

The nonnative western mosquitofish (Gambusia affinis) has negative impacts on age-0 least chub directly through competion and predation (Perkins et al. 1998, Mills et al. 2004), and may also indirectly affect least chub via exclusion from suitable rearing habitats. The least chub populations at Mona Springs and in other locations have declined as western mosquitofish have invaded and proliferated in the spring habitats (Perkins et al. 1998, Wilson and Whiting 2003). Mills et al. (2004) demonstrated that western mosquitofish prey upon and compete with least chub. In laboratory studies, age-0 least chub sought refuge while in the presence of western mosquitofish, and spent less time feeding; this resulted in reduced growth and a longer period during which least chub were vulnerable to predation (Mills et al. 2004). We hypothesize that western mosquitofish can also reduce growth of least chub by excluding them from shallow habitats in the wild. After hatching in the shallow water habitats, age-0 least chub may seek refuge from predatory western mosquitofish by utilizing the cooler pool habitats. Similarly, because western mosquitofish behave aggressively to compete with native fishes (Schoenherr 1981), adult least chub may choose to spawn in pool habitats to avoid such interactions. In either scenario, age-0 least chub would experience reduced growth in the cooler pool habitats, lengthening the time they are vulnerable to predation from other fish and increasing the likelihood of overwinter mortality. The com- pounding effects of western mosquitofish on least chub reduce the strength of individual year-classes and ultimately the viability of least chub populations.

Eradication of western mosquitofish from least chub habitats is not likely a viable option, as the nonnative species has proven resilient to such efforts (Marsh and Minckley 1990, Wilson and Whiting 2003). Managers must therefore manage the habitats such that least chub will be more likely to coexist successfully with western mosquitofish. A worthwhile study for managers would identify the temperature at which competition between western mosquitofish and least chub is minimized. Western mosquitofish require warm water habitats (Otto 1973); the species is able to survive cold winter temperatures in Utah by occupying pools associated with springs (Rees 1934). Reducing or eliminating warm shallow spring margins could reduce the prevalence and competitive ability of western mosquitofish by reducing the warm water refugia that enable them to thrive in these spring habitats (McHugh and Budy 2005). Age-0 least chub did demonstrate positive growth at $14.15^{\circ} \mathrm{C}$, and positive growth was estimated to occur above $12.5^{\circ} \mathrm{C}$. Whereas age-0 least chub could exhibit positive growth, the effects of colder water temperatures on reproduction and recruitment are not known; reducing shallow spring margins might have negative effects on least chub populations, adding to the current rate of decline of the species rather than stopping it. If competition between western mosquitofish and least chub could be reduced at lower water temperatures, additional research should examine the effects of temperature on spawning success and recruitment.

The thermal requirements for least chub fry can be used to establish protocols for propagating this species. Rearing facilities for least chub should utilize water temperatures between $20.7^{\circ}$ and $24.4^{\circ} \mathrm{C}$ to optimize growth of age- 0 least chub. Spawning has been documented at cooler temperatures (Crawford 1979, Baugh 1980); however, production of least chub could increase at warmer temperatures (Mills 1991). Further research is needed to determine the temperature range in which spawning will occur and at what temperature spawning can be maximized. By operating rearing facilities within the optimal temperature range, managers 
could increase the production of least chub and the rate at which they are available for stocking.

Optimal growth temperature for age-0 least chub $\left(22.3^{\circ} \mathrm{C}\right)$ was warmer than the spring water, indicating the importance of warm shallow spring margins as rearing habitats for survival and growth of age-0 least chub and ultimately for strong year-classes (Mills and Mann 1985). Habitats for this species should be managed to ensure that least chub have access to the shallow spring margins they use for rearing habitat. Additional research should examine the effects of temperature on spawning success and subsequent recruitment, and on interactions with other aquatic organisms, particularly western mosquitofish.

\section{ACKNOWLEDGMENTS}

Funding was provided by the Utah Division of Wildlife Resources and the Utah Reclamation Mitigation and Conservation Commission. We thank Mellisa Harvey and Andrea Severson for assistance with fish feeding and data collection.

\section{Literature Cited}

Angermeier, P.L. 1992. Predation by rock bass on other stream fishes: experimental effects of depth and cover. Environmental Biology of Fishes 34:171-180.

BAUGH, T.M. 1980. Spawning of the least chub (Iotichthys phlegethontis). Great Basin Naturalist 40:139-140.

Berkman, H.E., and C.F. RabENI. 1987. Effect of siltation on stream fish communities. Environmental Biology of Fishes 18:285-294.

Black, T., AND R.V. BulkLey. 1985. Growth rate of yearling Colorado squawfish at different water temperatures. Southwestern Naturalist 30:253-257.

Blinn, D.W., J. White, T. Pradetto, and J. O’Brien. 1998. Reproductive ecology and growth of a captive population of Little Colorado spinedace (Lepidomeda vittata: Cyprinidae). Copeia 1998:1010-1015.

Bulak, J.S., J.S. Crane, D.H. Secor, and J.M. Dean. 1997. Recruitment dynamics of striped bass in the SanteeCooper system, South Carolina. Transactions of the American Fisheries Society 126:133-143.

Castleberry, D.T., and J.J. CeCH, JR. 1986. Physiological responses of a native and an introduced desert fish to environmental stressors. Ecology 67:912-918.

Crawford, M. 1979. Reproductive modes of the least chub Iotichthys phlegethontis Cope. Master's thesis, Utah State University, Logan.

Cross, J.N. 1978. Status and ecology of the Virgin River roundtail chub, Gila robusta seminude (Osteichthyes: Cyprinidae). Southwestern Naturalist 23:519-528.

Durham, B.W., AND G.R. Wilde. 2005. Relationship between hatch date and first-summer growth of five species of prairie-stream cyprinids. Environmental Biology of Fishes 72:45-54.

Gerking, S.D., AND R.M. LEE. 1983. Thermal limits for growth and reproduction in the desert pupfish Cyprinodon n. nevadensis. Physiological Zoology 56:1-9.

Junk, W.J., P.B. Bayley, and R.E. Sparks. 1989. The flood pulse concept in river-floodplain systems. Canadian Special Publication of Fisheries and Aquatic Sciences 106:110-127.

KWAK, T.J. 1988. Lateral movement and use of flood-plain habitat by fishes in the Kankakee River, Illinois. American Midland Naturalist 120:241-249.

ManN, R.H.K., AND J.A.B. BASs. 1997. The critical water velocities of larval roach (Rutilus rutilus) and dace (Leuciscus leuciscus) and implications for river management. Regulated Rivers: Research and Management 13:295-301.

Marsh, P.C., AND W.L. Minckley. 1990. Management of endangered Sonoran topminnow at Bylas Springs, Arizona: description, critique, and recommendations. Great Basin Naturalist 50:265-272.

McHugh, P., AND P. Budy. 2005. An experimental evaluation of competitive and thermal effects on brown trout (Salmo trutta) and Bonneville cutthroat trout (Oncorhynchus clarkii utah) performance along an altitudinal gradient. Canadian Journal of Fisheries and Aquatic Sciences 62:2784-2795.

Mills, C.A. 1991. Reproduction and life history. Pages 483-508 in I.S. Winfield and J.S. Nelson, editors, Cyprinid fishes: systematics, biology, and exploitation. Chapman and Hall, London.

Mills, C.A., AND R.H.K. Mann. 1985. Environmentallyinduced fluctuations in year-class strength and their implications for management. Journal of Fish Biology 27 (supplement A):209-226.

Mills, M.D., R.B. Rader, and M.C. Belk. 2004. Complex interactions between native and invasive fish: the simultaneous effects of multiple negative interactions. Oecologia 141:713-721.

Modde, T., R.T. Muth, And G.B. Haines. 2001. Floodplain wetland suitability, access, and potential use by juvenile razorback suckers in the Middle Green River, Utah. Transactions of the American Fisheries Society 130:1095-1105.

Neill, C., AND R.E. Turner. 1987. Comparison of fish communities in open and plugged backfilled canals in Louisiana coastal marshes. North American Journal of Fisheries Management 7:57-62.

OLSEN, D.G., AND M.C. BELK. 2005. Relationship of diurnal habitat use of native stream fishes of the eastern Great Basin to presence of introduced salmonids. Western North American Naturalist 65:501-506.

Отто, R.G. 1973. Temperature tolerance of the mosquitofish, Gambusia affinis (Baird and Girard). Journal of Fish Biology 5:575-585.

Perkins, M.J., L.D. Lentsch, And J. Mizzi. 1998. Conservation agreement and strategy for least chub (Iotichthys phlegethontis). Utah Division of Wildlife Resources, Salt Lake City.

Power, M.E. 1984. Depth distributions of armored catfish: predator-induced resource avoidance? Ecology 65:523-528.

ReEs, D.M. 1934. Notes on mosquito fish in Utah, Gambusia affinis (Baird and Girard). Copeia 1934:157-159.

RiCKER, W.E. 1979. Growth rates and models. Pages 677743 in W.S. Hoar, D.J. Randall, and J.R. Brett, editors, 
Fish physiology. Volume VIII. Bioenergetics and growth. Academic Press, New York.

Robinson, A.T., AND M.R. ChiLDs. 2001. Juvenile growth of native fishes in the Little Colorado River and in a thermally modified portion of the Colorado River. North American Journal of Fisheries Management 21:809-815.

Rosenberger, A., And P.L. Angermeier. 2003. Ontogenetic shifts in habitat use by the endangered Roanoke logperch (Percina rex). Freshwater Biology 48:1563-1577.

SABo, M.J., AND W.E. Kelso. 1991. Relationship between morphometry of excavated floodplain ponds along the Mississippi River and their use as fish nurseries. Transactions of the American Fisheries Society 120: $552-561$.

SANDSTRÖM, A., AND P. KARÅS. 2002. Tests of artificial substrata as nursery habitat for young fish. Journal of Applied Ichthyology 18:102-105.

SCHEIDEGGaR, K.J., AND M.B. BAIN. 1995. Larval fish distribution and microhabitat use in free-flowing and regulated rivers. Copeia 1995:125-135.

Schoenherr, A.A. 1981. The role of competition in the replacement of native fishes by introduced species. Pages 173-203 in R.J. Naiman and D.L. Soltz, editors, Fishes in North American deserts. Wiley, New York.

Selong, J.H., T.E. McMahon, A.V. Zale, and F.T. BarROWS. 2001. Effect of temperature on growth and survival of bull trout, with application of an improved method for determining thermal tolerance in fishes. Transactions of the American Fisheries Society 130: 1026-1037.

Shuter, B.J., AND J.R. Post. 1990. Climate, population viability, and the zoogeography of temperate fishes.
Transactions of the American Fisheries Society 119: 314-336.

Sigler, W.F., And J.W. Sigler. 1987. Fishes of the Great Basin, a natural history. University of Nevada Press, Reno. 425 pp.

Sigler, W.F., AND J.W. Sigler. 1996. Fishes of Utah: a natural history. University of Utah Press, Salt Lake City. 375 pp.

Snedden, G.A., W.E. Kelso, and D.A. Rutherford. 1999. Diel and seasonal patterns of spotted gar movement and habitat use in the lower Atchafalaya River Basin, Louisiana. Transactions of the American Fisheries Society 128:144-154.

SPSS, INC. 1996. SPSS ${ }^{\circledR}$ base 7.0 for Windows ${ }^{\mathrm{TM}}$ user's $^{\text {' }}$ guide. SPSS, Inc., Chicago, IL.

2001. SigmaPlot ${ }^{\circledR}$ version 7.0 for Windows ${ }^{\mathrm{TM}}$ user's guide. SPSS, Inc., Chicago, IL.

U.S. Fish and Wildlife Service. 1997. Recovery plan for the rare species of Soldier Meadows. Portland, OR.

Werner, E.E., AND D.J. HALL. 1988. Ontogenetic habitat shifts in bluegill: the foraging rate-predation risk trade-off. Ecology 69:1352-1366.

Williams, J.E., AND C.E. Bond. 1983. Status and life history notes on the native fishes of the Alvord Basin, Oregon and Nevada. Great Basin Naturalist 43:409420 .

WiLson, K.W., AND J.C. Whiting. 2003. Least chub (Iotichthys phlegethontis) monitoring summary Central Region, 2002. Utah Division of Wildlife Resources, Publication 03-08, Salt Lake City.

Received 1 November 2005 Accepted 13 April 2006 